\title{
BUMDES DI KECAMATAN KABAWETAN : KAJIAN MANFAAT BAGI MASYARAKAT
}

\author{
Indah Permata Sari $^{1)}$, Retno A Ekaputri ${ }^{2)}$ \\ ${ }^{1}$ Jurusan Ekonomi Pembangunan Fakultas Ekonomi dan Bisnis Universitas Bengkulu \\ Email: indahpermatas128@gmail.com \\ ${ }^{2}$ Jurusan Ekonomi Pembangunan Fakultas Ekonomi dan Bisnis Universitas Bengkulu
} Email: retnoae@unib.ac.id

\begin{abstract}
The purpose of this study was to determine the condition of BUMDes in Kabawetan district, Kepahiang Regency. The analytical method used is descriptive qualitative analysis. The data used in this research is secondary data. The results of this study indicate that the condition of BUMDes has gone well, BUMDes have been equipped with village regulations and village head decisions with adequate capital participation. Then BUMDes has a complete management and has several types of businesses.
\end{abstract}

Keywords : BUMDe, Rural Economic

\section{PENDAHULUAN}

Pembangunan merupakan suatu usaha yang mampu meningkatkan kualitas hidup dengan cara menggunakan potensi atau sumberdaya alam yang dimiliki oleh wilayah tersebut. Potensi dapat berupa sumberdaya alam, sumberdaya manusia serta sumberdaya buatan (infrastruktur, sarana prasarana atau lain-lain). Apabila sumberdaya yang dikelola dapat dimanfaatkan dengan baik maka akan menentukan tingkat keberhasilan suatu pembangunan. Selain itu, pembangunan juga memiliki tujuan untuk membangun kemandirian, termasuk pembangunan pedesaan. Salah satu misi dari pemerintah dalam membangun daerah pedesaan adalah dengan melalui pemberdayaan masyarakat yang nantinya dapat meningkatkan produktivitas dan keanekaragaman usaha pedesaan, ketersediaan sarana dan fasilitas untuk mendukung ekonomi pedesaan, membangun dan memperkuat institusi yang mendukung rantai produksi dan pemasaran, serta mengoptimalkan sumberdaya sebagai dasar pertumbuhan ekonomi pedesaan.

Pembangunan pedesaan yaitu, pertama, memberdayakan ekonomi masyarakat desa dalam rangka peningkatan kapasitas masyarakat dalam perubahan struktur masyarakat pedesaan tradisional ke masyarakat pedesaan yang maju dan mandiri. Kedua, meningkatkan kualitas sumberdaya manusia pedesaan agar memiliki dasar yang memadai untuk meningkatkan dan memperkuat produktivitas serta daya saing. Ketiga, pembangunan prasarana agar sumber daya yang ada di pedesaan dapat di manfaatkan secara optimal. Keempat, pembangunan kelembagaan pedesaan agar pembangunan pedesaan dapat dilaksanakan secara efektif dan efisien.

Tujuan pembangunan pedesaan adalah untuk memberi peluang bagi kemampuan daerah dan pedesaan sebagai tulang punggung ekonomi regional maupun nasional, tidak lupa untuk tetap memberdayakan masyarakat guna membangun daya dengan mendorong, memotivasi, dan membangkitkan kesadaran akan adanya potensi yang dimilikinya serta terus berupaya untuk mengembangkannya. Pentingnya pemberdayaan dalam rangka memandirikan masyarakat untuk peningkatan taraf hidup yang lebih layak serta kemajuan ekonomi, seperti modal, teknologi, informasi dan pasar.

Kemajuan ekonomi di tingkat provinsi dapat tercapai jika kabupaten memiliki kegiatan ekonomi yang baik, kemajuan ini akan tercapai karena adanya bantuan dari ekonomi pedesaan yang kuat yang mampu meningkatkan kesejahteraan masyarakat luas. Hal ini mampu menjamin pemerintah 
untuk dapat menerapkan disemua tingkat pembangunan dan keputusan berdasarkan kebutuhan nyata dari masyarakat, sehingga pembangunan pedesaan menjadi salah satu cara dalam upaya mengentaskan kemiskinan dan meningkatkan kesejahteraan. Berawal dari pengembangan berbasis ekonomi di pedesaan yang sudah lama dijalankan pemerintah mulai dari program IDT intruksi presiden guna mengentaskan kemiskinan di pedesaan tertinggal pada masa Pemerintahan Orde Baru, kemudian program P3DT (Pembangunan Prasarana Pendukung Desa Tertinggal) di tahun 1995, serta di tahun 1998 pemerintah meluncurkan program PPK (yang sekarang menjadi PNPM Mandiri) dengan memfokuskan penyediaan dana berputar dengan menggunakan lembaga keuangan yang dimiliki masyarakat.

Program-program tersebut belum mampu memberikan hasil yang sesuai keinginan bersama dikarenakan salah satu faktor yaitu intevensi pemerintah sehingga menghambat kreatifitas dan inovasi masyarakat desa dalam mengelola dan menjalankan roda ekonomi di pedesaan. Mekanisme kelembagaan ekonomi di pedesaan tidak berjalan dengan baik maka dapat membawa ketergantungan masyarakat pedesaan terhadap bantuan pemerintah dan menjadikan desa tersebut sebagai desa yang tidak berbasis kemandirian. Hal tersebut akan menjadi perhatian serius dari pemerintah hingga akhirnya pemerintah mulai menerapkan program baru untuk pedesaan yang harapannya dapat mampu menjalankan roda perekonomian di pedesaan melalui pendirian kelembagaan ekonomi yang sepenuhnya dikelola oleh masyarakat desa yaitu Badan Usaha Milik Desa (BUMDes) sebagai program untuk meningkatkan kemandirian perekonomian desa.

BUMDes sebagai program baru dalam usaha meningkatkan ekonomi desa berdasarkan kebutuhan masyarakat dan potensi desa, yang pengelolaannya sepenuhnya akan dilaksanakan oleh masyarakat desa, yaitu dari desa, oleh desa, dan untuk desa. Serta cara kerja BUMDes dengan menampung kegiatan-kegiatan ekonomi masyarakat dalam bentuk kelembagaan atau badan usaha yang dikelola secara profesional namun tetap pada potensi asli desa. Usaha masyarakat dalam membangun program baru ini dapat menjadikan lebih produktif dan efektif sehingga kedepannya diharapkan BUMDes mampu menjadi lembaga yang menampung kegiatan ekonomi masyarakat yang berkembang sesuai dengan potensi desa atau ciri khas desa masing-masing yang nantinya dapat meningkatkan kesejahteraan masyarakat desa.

Menurut Peraturan Pemerintah Republik Indonesia Nomor 43 Tahun 2014 tentang Peraturan Pelaksanaan Undang-Undang Nomor 6 Tahun 2014 tentang desa pada pasal 1 angka 7 bahwa Badan Usaha Milik Desa adalah badan usaha yang seluruh atau sebagian besar modalnya dimiliki oleh desa melalui penyertaan secara langsung yang berasal dari kekayaan desa yang dipisahkan guna mengelola asset, jasa pelayanan, dan usaha lainnya untuk sebesar-besarnya kesejahteraan masyarakat desa. Badan Usaha Milik Desa (BUMDes) adalah usaha desa yang dibentuk atau didirikan oleh pemerintah desa yang kepemilikan modal dan pengelolaannya dilakukan oleh pemerintah desa dan masyarakat. Tujuan BUMDes adalah dapat meningkatkan kesejahteraan ekonomi warga melalui pengembangan usaha ekonomi masyarakat desa sesuai dengan potensi desa masing-masing. BUMDes disetiap daerahnya berbeda-beda sesuai potensi desa yang dimiliki sehingga jenis usahanya pun berbeda dari mulai jenis usaha bahan sembako seperti toko kelontong, mini market desa, sewa alat-alat proyek bangunan hingga jenis usaha seperti jasa-jasa lain termasuk desa wisata.

BUMDes yang merupakan pilar kegiatan ekonomi di desa yangberfungsi sebagai lembaga sosial (social institution) dan komersial (commercial institution). BUMDes sebagai lembaga sosial berpihak kepada kepentingan masyarakat melalui kontribusinya dalam penyediaan pelayanan sosial. Sedangkan sebagai lembaga komersial bertujuan mencari keuntungan melalui penawaran sumberdaya lokal (barang dan jasa) ke pasar. Dalam menjalankan usahanya prinsip efisiensi dan efektifitas harus selalu ditekankan. BUMDes sebagai badan hukum, dibentuk berdasarkan tata perundang-undangan yang berlaku, dan sesuai dengan kesepakatan yang terbangun di masyarakat desa. Dengan demikian, bentuk BUMDes dapat beragam di setiap desa di Indonesia. Ragam 
bentuk ini sesuai dengan karakteristik lokal, potensi, dan sumber daya yang dimiliki masingmasing desa. Pengaturan lebih lanjut tentang BUMDes diatur melalui Peraturan Daerah (Perda).

BUMDes memang berbeda dan memiliki keunikan tersendiri jika dibandingkan dengan usaha lainnya. Keunikan BUMDes terletak pada skema swadaya yang berasaskan gotong royong dan kekeluargaan. Pemerintah Desa secara kolektif harus bekerja sama dengan masyarakat untuk membangun BUMDes sesuai dengan potensi lokal masing-masing desa. Hal ini tentu berbeda dengan unit usaha lain seperti koperasi atau unit usaha ekonomi kolektif lainnya yang terkesan eksklusif dan hanya melibatkan anggotanya saja.

Meskipun demikian, pengembangan BUMDes di Indonesia masih memiliki kelemahan. Yunanto (2003: 2) dalam policy papernya menjabarkan setidaknya lima kelemahan dalam pengembangan BUMDes saat ini, yakni:

1. Tidak maksimalnya penataan kelembagaan desa. Akibatnya, BUMDes belum benar-benar terinstitusionalisasi dalam pemerintahan desa dan perekonomian desa.

2. Adanya keterbatasan sumberdaya manusia di desa untuk mengelola dan mengembangkan BUMDes yang akuntabel dan berkinerja baik.

3. Inisiasi-inisiasi dari tingkat lokal untuk menggerakan potensi ekonomi masih rendah, khususnya bagi peningkatan kesejahteraan sosial dan ekonomi warga desa.

4. Lemahnya proses konsolidasi dan kerja sama antar stakeholder (pemangku kepentingan) untuk mewujudkan BUMDes sebagai sebuah lembaga ekonomi yang berperan meningkatkan ekonomi kerakyatan.

5. Responsivitas Pemerintah Daerah masih lemah dalam melihat BUMDes sebagai program unggulan untuk memberdayakan desa dan kesejahteraan masyarakat.

Berkaitan dengan kelemahan yang telah dijabarkan di atas, BUMDes tidak akan mampu berkembang dengan baik jika hanya menggunakan pendekatan teknokratis-manajerial (Yunanto, 2003: 6). Oleh karena itu, menurut Yunanto BUMDes yang baik harus ditopang oleh empat pilar utama. Empat pilar tersebut yakni:

1. Pilar ekonomi (aset, modal, manajemen, kewirausahaan, produksi, distribusi, dan pasar)

2. Pilar sosial (modal sosial)

3. Pilar politik

4. Pilar hukum

Dari data Kementrian Desa Pembangunan Daerah Tertinggal dan Transmigrasi, tercatat sebanyak 41.000 BUMDes telah berkembang dari total 74.957 desa di Indonesia. Berbicara mengenai BUMDes Provinsi Bengkulu jauh lebih tertinggal dari Pulau Jawa yang lebih dulu mengembangkan BUMDes. Di lihat dari data Dinas Pemberdayaan Masyarakat dan Desa, BUMDes di Provinsi Bengkulu baru mulai berkembang pada tahun 2016. Untuk BUMDes di Provinsi Bengkulu itu sendiri tercatat ada 1.032 unit kegiatan BUMDes yang tesebar dari 1341 desa. Berikut daftar jumlah BUMDes di Provinsi Bengkulu:

Tabel 1 Daftar jumlah BUMDes di Provinsi Bengkulu Tahun 2018

\begin{tabular}{lrrrrrr}
\hline Kabupaten & $\begin{array}{c}\text { Jumlah } \\
\text { Kecamatan }\end{array}$ & $\begin{array}{c}\text { Jumlah } \\
\text { Desa }\end{array}$ & $\begin{array}{c}\text { Jumlah } \\
\text { BUMDes }\end{array}$ & $\begin{array}{c}\text { BUMDes } \\
\text { Aktif }\end{array}$ & $\begin{array}{c}\text { Rasio } \\
\text { Desa- } \\
\text { BUMDes }\end{array}$ & $\begin{array}{c}\text { Rasio } \\
\text { BUMDes } \\
\text { Aktif }\end{array}$ \\
\hline Bengkulu Selatan & 11 & 142 & 131 & 118 & $92 \%$ & $90 \%$ \\
Rejang Lebong & 14 & 122 & 122 & 62 & $100 \%$ & $51 \%$ \\
Bengkulu Utara & 19 & 215 & 115 & 87 & $53 \%$ & $76 \%$ \\
Kaur & 15 & 192 & 64 & 48 & $33 \%$ & $75 \%$ \\
\hline
\end{tabular}




\begin{tabular}{lrrrrrr}
\hline Kabupaten & $\begin{array}{c}\text { Jumlah } \\
\text { Kecamatan }\end{array}$ & $\begin{array}{c}\text { Jumlah } \\
\text { Desa }\end{array}$ & $\begin{array}{c}\text { Jumlah } \\
\text { BUMDes }\end{array}$ & $\begin{array}{c}\text { BUMDes } \\
\text { Aktif }\end{array}$ & $\begin{array}{c}\text { Rasio } \\
\text { Desa- } \\
\text { BUMDes }\end{array}$ & $\begin{array}{c}\text { Rasio } \\
\text { BUMDes } \\
\text { Aktif }\end{array}$ \\
\hline Seluma & 13 & 182 & 153 & 92 & $84 \%$ & $60 \%$ \\
Muko-Muko & 15 & 148 & 126 & 99 & $85 \%$ & $79 \%$ \\
Lebong & 12 & 93 & 79 & 14 & $85 \%$ & $18 \%$ \\
Kepahiang & 8 & 105 & 105 & 100 & $100 \%$ & $95 \%$ \\
Bengkulu Tengah & 10 & 142 & 137 & 102 & $96 \%$ & $74 \%$ \\
\hline \multicolumn{1}{c}{ Jumlah } & 117 & 1341 & 1.032 & 722 & $77 \%$ & $70 \%$ \\
\hline
\end{tabular}

Sumber: Dinas Pemberdayaan Masyarakarat dan Desa Provinsi Bengkulu, 2018

Dilihat dari Tabel 1 di atas jumlah BUMDes paling banyak terdapat di Kabupaten Bengkulu Tengah yaitu sebanyak 137 unit. Akan tetapi jika dilihat dari tingkat rasio keaktifan BUMDes yang paling aktif ada di Kabupaten Kepahiang yaitu dengan rasio 95\% dari 100 unit BUMDes yang ada. Kabupaten Kepahiang itu sendiri memiliki 8 kecamatan yang dimana setiap desa di kecamatan tersebut rata-rata telah memiliki BUMDes. Salah satu Kecamatan yang telah memiliki BUMdes adalah Kecamatan Kabawetan yang terdiri dari 14 desa. BUMDes di Kecamatan ini tergolong paling aktif hal ini ditunjukkan dengan tabel berikut ini:

Tabel 2 BUMDes di Kabupaten Kepahiang Tahun 2018

\begin{tabular}{lccc}
\hline Kecamatan & \multirow{2}{*}{ Jumlah Desa } & $\begin{array}{c}\text { Jumlah BUMDes } \\
\text { Aktif }\end{array}$ & $\begin{array}{c}\text { Jumlah BUMDes } \\
\text { Tidak Aktif }\end{array}$ \\
\hline Bermani Ilir & 18 & 17 & 1 \\
Ujan Mas & 16 & 15 & 1 \\
Tebat Karai & 13 & 12 & 1 \\
Kepahiang & 16 & 15 & 1 \\
Merigi & 7 & 7 & - \\
Kabawetan & 14 & 14 & - \\
Seberang Musi & 13 & 12 & 1 \\
Muara Kemumu & 8 & 8 & - \\
\hline
\end{tabular}

Sumber: Dinas Pemberdayaan Masyarakat dan Desa Provinsi Bengkulu, 2018

Kecamatan Kabawetan juga memiliki beberapa jenis produk unggulan desa (prudes) seperti kopi. Selain itu kecamatan Kabawetan memiliki kerjasama dengan BULOG dalam kegiatan BUMDes. Dengan berbagai kegiatan usaha yang ada di Kecamatan Kabawetan tersebut diharapkan bisa berkembang lagi sehingga mampu meningkatkan pendapatan desa serta mengembangkan perekonomian yang ada di masyarakat. Berangkat dari titik tolak tersebut penulis merasa perlu untuk mengangkat isu ini sebagai sebuah tema dalam penelitian yang berjudul Analisis kondisi BUMDes di Kecamatan Kabawetan Kabupaten Kepahiang.

\section{LANDASAN TEORI}

\section{Teori Pembangunan Ekonomi}

Pembangunan ekonomi adalah suatu proses yang menyebabkan pendapatan per kapita penduduk suatu masyarakat meningkat. Pembangunan ekonomi diartikan sebagai serangkaian usaha dalam suatu perekonomian untuk mengembangkan kegiatan ekonomi sehingga infrastruktur lebih banyak tersedia, perusahaan semakin banyak dan semakin berkembang, taraf pendidikan semakin tinggi dan teknologi meningkat. 
Menurut Todaro (2009:16) dalam pembangunan ekonomi harus ada suatu proses multimimensional yang melibatkan perubahan mendasar dalam struktur sosial, sikap-sikap masyarakat dan kelembagaan yang diiringi dengan peningkatan pertumbuhan ekonomi, pengurangan ketimpangan dan kemiskinan. Adapun nilai utama pembangunan menurut Todaro (2009:20), antara lain :

1. Kemampuan untuk memenuhi kebutuhan dasar.

2. Penghargaan terhadap diri sendiri.

3. Memiliki kemampuan untuk memilih

Adapun tiga objek pembangunan menurut Todaro (2009:22) adalah sebagai berikut:

1. Meningkatkan ketersediaan serta memperluas distribusi barang kebutuhan dasar hidup seperti makanan, perlindungan, kesehatan dan keamanan.

2. Meningkatkan standar hidup, termasuk meningkatkan pendapatan, perluasan kesempatan kerja, pendidikan, dan perhatian lebih kepada budaya dan nilai kemanusiaan, dimana semua hal tersebut dilakukan tidak hanya untuk peningkatan secara material. Namun juga untuk meningkatkan harga diri baik secara individu maupun nasional.

3. Memperluas ketersediaan pilihan sosial dan ekonomi untuk masyarakat dan nasional dengan membebaskan mereka dari ketidakmandirian.

Tujuan utama pembangunan ekonomi adalah menciptakan tingkat pertumbuhan GNP yang setinggi-tingginya, akan tetapi diikuti dengan pemberantasan kemiskinan, penanggulangan ketimpangan pendapatan, penyediaan lapangan kerja, pendidikan yang lebih baik, peningkatan standar kesehatan dan nutrisi, perbaikan kondisi lingkungan lingkungan hidup, pemerataan kesempatan, pemerataan kebebasan individual dan penyegaran kehidupan budaya.Ada beberapa manfaat yang diperoleh dari pembangunan ekonomi, antara lain :

1. Meningkatkan GNP.

2. Mengurangi pengangguran.

3. Meningkatnya kemakmuran.

4. Pengelolaan alam yang lebih baik.

5. Modal yang terkumpul.

Pertumbuhan ekonomi ialah sebagai kenaikan jangka panjang dalam kemampuan suatu negara untuk menyediakan semakin banyak jenis barang-barang ekonomi kepada penduduknya; kemampuan ini tumbuh sesuai dengan suatu kemajuan tekonologi, dan penyesuaian kelembagaan dan ideologis yang diperlukannya.

\section{Pertumbuhan Ekonomi}

Pengertian pertumbuhan ekonomi mempunyai tiga komponen. Pertama, pertumbuhan ekonomi suatu bangsa terlihat dari meningkatnya secara terus-menerus persediaan barang; yang kedua, teknologi maju adalah faktor dalam pertumbuhan ekonomi yang menentukan derajat pertumbuhan kemampuan dalam penyediaan aneka macam barang kepada penduduk; yang ketiga, penggunaan teknologi secara luas dan efisien memerlukan adanya suatu penyesuaian di bidang kelembagaan dan ideologi sehingga inovasi yang dihasilkan oleh ilmu pengetahuan umat manusia bisa dimanfaatkan secara tepat. Tekonologi modern misalnya, tidak cocok dengan corak/kehidupan desa, pola keluarga besar, usaha keluarga dan buta huruf.

Menurut teori pertumbuhan ekonomi Solow Swan pertumbuhan ekonomi tergantung kepada pertambahan penyediaan faktor-faktor produksi dan tingkat kemajuan teknologi. Berdasarkan penelitiannya, ia mengatakan bahwa peran dari kemajuan teknologi di dalam pertumbuhan 
ekonomi sangat tinggi. Pandangan teori ini didasarkan kepada anggapan yang mendasari analisis klasik, yaitu perekonomian akan tetap mengalami tingkat pengerjaan penuh (full employment) dan kapasitas peralatan modal akan tetap sepenuhnya digunakan sepanjang waktu. Dengan kata lain, sampai dimana perekonomian akan berkembang tergantung pada pertambahan penduduk, akumulasi kapital, dan kemajuan teknologi.

Selanjutnya, menurut teori ini, rasio modal-output (capital-output ratio $=$ cor) bisa berubah (bersifat dinamis). Dengan kata lain, untuk menciptakan sejumlah output tertentu bisa digunakan jumlah modal yang berbeda-beda dengan bantuan tenaga kerja yang jumlahnya berbeda-beda pula sesuai dengan yang dibutuhkan. Jika lebih banyak modal yang digunakan, maka lebih banyak tenaga kerja yang digunakan. Begitu pula sebaliknya. Dengan adanya "keluwesan" (fleksibelitas) ini suatu perekonomian mempunyai kebebasan yang tak terbatas dalam menentukan kombinasi modal dan tenaga kerja yang akan digunakan untuk menghasilkan tingkat output tertentu. Solow membangun modelnya disekitar asumsi berikut:

1. Ada satu komoditi gabungan yang diproduksi.

2. Yang dimaksud output netto, yaitu sesudah dikurangi biaya penyusutan modal.

3. Return to scale bersifat konstan. Dengan kata lain, fungsi produk adalah homogen pada derajat pertama.

4. Dua faktor produksi buruh dan modal, dibayar sesuai dengan produktivitas fisik marginal mereka.

5. Harga dan upah fleksibel.

6. Buruh terpekerjakan secara penuh.

7. Stok modal yang ada juga terpekerjakan secara penuh.

8. Buruh dan modal dapat disubtitusikan satu sama lain.

9. Kemajuan teknik bersifat netral.

Robert Solow dari MIT dan Trevor Swan dari Australian National University (Boediono, 1981) secara sendiri-sendiri mengembangkan model pertumbuhan ekonomi yang sekarang sering disebut dengan nama model pertumbuhan Neo-Klasik. Seperti halnya dengan model Harrod-Domar, model Solow-Swan memusatkan perhatiannya pada bagaimana pertumbuhan penduduk, akumulasi capital, kemajuan teknologi dan output saling berinteraksi dalam proses pertumbuhan ekonomi.

\section{Badan Usaha Milik Desa}

\section{Definisi Badan Usaha Milik Desa}

Dalam UU Nomor 32 Tahun 2004 dan PP Nomor 72 Tahun 2005 diamanatkan bahwa dalam meningkatkan pendapatan masyarakat dan desa, pemerintah desa dapat mendirikan Badan Usaha Milik Desa (BUMDes) sesuai dengan kebutuhan dan potensi desa. Dalam hal perencanaan dan pembentukannya, BUMDes dibangun atas prakarsa (inisiasi masyarakat), serta mendasarkan pada prinsip-prinsip kooperatif, partisipatif dan emansipatif, dengan dua prinsip yang mendasari, yaitu member base dan self help. Hal ini penting mengingat bahwa profesionalime pengelolaan BUMDes benar-benar didasarkan pada kemauan (kesepakatan) masyarakat banyak (member base), serta kemampuan setiap anggota untuk mandiri dalam memenuhi kebutuhan dasarnya (self help), baik untuk kepentingan produksi (sebagai produsen) maupun konsumsi (sebagai konsumen) harus dilakukan secara professional dan mandiri.

Telah dikemukakan diatas bahwa berdirinya Badan Usaha Milik desa ini karena sudah dikatakan bahwa dalam meningkatkan pendapatan masyarakat dan desa, pemerintah desa dapat mendirikan badan usaha milik desa. Pilar lembaga BUMDes ini merupakan institusi sosial-ekonomi desa yang betul-betul mampu sebagai lembaga komersial yang mampu berkompetisi ke luar desa. 
BUMDes sebagai institusi ekonomi rakyat lembaga komersial, pertama-tama berpihak kepada pemenuhan kebutuhan (produktif maupun konsumtif) masyarakat adalah melalui pelayanan distribusi penyediaan barang dan jasa. Hal ini diwujudkan dalam pengadaan kebutuhan masyarakat yang tidak memberatkan (seperti: harga lebih murah dan mudah mendapatkannya) dan menguntungkan bagi masyarakat.

\section{Tujuan BUMDes}

Berikut ini adalah tujuan utama dari pendirian BUMDes:

1. Mendorong perkembangan perekonomian desa

2. Meningkatkan pendapatan asli desa

3. Meningkatkan kreatifitas dan peluang usaha ekonomi produktif masyarakat desa yang berpenghasilan rendah

4. Mendorong berkembangan usaha mikro sektor informal

Terdapat tujuh ciri utama yang membedakan BUMDes dengan lembaga ekonomi komersial pada umumnya yaitu:

1. Badan ini dimiliki oleh desa dan dikelola secara bersama

2. Modal usaha bersumber dari desa (51\%) dan dari masyarakat (49\%) melalui penyertaan modal (saham dan andil)

3. Operasionalisasinya menggunakan falsafah bisnis yang berakar dari budaya lokal (local wisdom )

4. Bidang usaha yang dijalankan berdasarkan pada potensi dan hasil informasi pasar

5. Keuntungan yang diperoleh ditujukan untuk meningkatkan kesejahteraan masyarakat melalui kebijakan desa (village policy)

6. Difasilitasi oleh Pemerintah, Pemprov, Pemkab, dan Pemdes

7. Pelaksanaan operasionalisasi dikontrol secara bersama (Pemdes,BPD, dan anggota)

\section{Pendirian BUMDes}

Berikut ini adalah syarat pembentukan BUMDes menurut Permendagri Nomor 39 Tahun 2010:

1. Atas inisiatif pemerintah desa dan atau masyarakat, terutama dalam berdasarkan musyawarah warga desa

2. Adanya potensi usaha masyarakat

3. Sesuai dengan kebutuhan masyarakat, terutama dalam pemenuhan kebutuhan pokok

4. Tersedianya sumber daya desa yang belum dimanfaatkan secara optimal terutama kekayaan desa

5. Tersedianya sumber daya manusia yang mampu mengelola badan usaha sebagai aset penggerak perekonomian masyarakat desa

6. Adanya unit-unit usaha masyarakat yang merupakan kegiatan ekonomi warga masyarakat yang dikelola secara parsial dan kurang terakomodasi

7. Untuk meningkatkan pendapatan masyarakat dan pendapatan asli desa.

Mekanisme pembentukan BUMDes menurut Permendagri Nomor 39 Tahun 2010 adalah sebagai berikut:

1. Rembug desa/musyawarah untuk menghasilkan kesepakatan

2. Kesepakatan dituangkan dalam AD/ART yang sekurang-kurangnya berisi: organisasi dan tata kerja, penetapan personil, sistem pertanggung jawaban dan pelaporan, bagi hasil, dan kepailitan

3. Pengusulan materi kesepakatan sebagai draft peraturan desa 
4. Penerbitan peraturan desa. Setelah segala persyaratan pendirian BUMDes sudah terpenuhi, kemudian BUMDes disahkan dan ditetapkan dengan peraturan desa.

Peraturan lebih lanjut terkait dengan tata cara pendirian dan pengelolaan BUMDes menurut PP Nomor 72 tahun 2005 diserahkan kepada pemerintah daerah masing-masing di seluruh Indonesia. Artinya pembentukan BUMDes disetiap daerah adalah berbeda satu dengan yang lainnya,tergantung pada kebutuhan dan potensi daerahnya masing-masing.

Peraturan daerah yang diterbitkan terkait dengan tata cara pendirian dan pengelolaan BUMDes sekurang-kurangnya memuat hal sebagai berikut:

1. Bentuk badan hukum

2. Kepengurusan

3. Hak dan kewajiban

4. Permodalan

5. Bagi hasil usaha

6. Kerjasama dengan pihak ketiga

\section{Pengelolaan BUMDes}

Berikut ini adalah persyaratan untuk pengelolaan BUMDes:

1. Pengurus yang berpengalaman dan atau profesional

2. Mendapat pengawasan secara internal maupun eksternal

3. Mendapat pembinaan dari manajemen

4. Menganut prinsip transparansi, akuntabel, dapat dipercaya danrasional

5. Melayani kebutuhan masyarakat dengan baik dan adil. Pengelolaan BUMDes harus dijalankan dengan menggunakan prinsip kooperatif, partisipatif, transparansi, kesetaraan, akuntabel, berkelanjutan, dan profesional.

Tujuan pengelolaan BUMDes adalah sebagai berikut :

1. Meningkatkan pelayanan kepada masyarakat (Standar PelayananMinimal), agar berkembang usaha masyarakat di desa.

2. Memberdayakan desa sebagai wilayah yang otonom berkenaan dengan usaha-usaha produktif bagi upaya pengentasan kemiskinan, pengangguran, dan peningkatan PADes.

3. Meningkatkan kemandirian dan kapasitas desa serta masyarakat dalam melakukan penguatan ekonomi di desa. Tata cara pengelolaan dan pendirian BUMDes telah diatur secara terperinci oleh Pemerintah Kabupaten/Kota melalui Perda. Selanjutnya tata cara ini akan dijadikan acuan bagi desa untuk mendirikan BUMDes. Masyarakat dan pemerintah desa saling bekerja sama untuk memprakarsai pendirian BUMDes melalui forum musyawarah desa/rembug desa.

\section{Keuangan BUMDES}

Masalah keuangan dalam BUMDes secara umum diatur dalam Kemendagri Nomor 39 Tahun 2010 dan PP Nomor 72 Tahun 2005. Berikut ini adalah sumber-sumber permodalan BUMDes:

1. Pemerintah Desa

2. Tabungan masyarakat

3. Bantuan Pemerintah, Pemerintah Provinsi, dan Pemerintah Kabupaten/ Kota

4. Pinjaman

5. Penyertaan modal pihak lain atau kerja sama bagi hasil atas dasar saling menguntungkan. 
BUMDes didirikan berdasarkan kebutuhan dan potensi desa yang merupakan prakarsa masyarakat desa. Terdapat tujuh ciri utama yang membedakan BUMDes dengan lembaga ekonomi komersial pada umumnya yaitu:

1. Badan ini dimiliki oleh desa dan dikelola secara bersama

2. Modal usaha bersumber dari desa $(51 \%)$ dan dari masyarakat $(49 \%)$ melalui penyertaan modal (saham dan andil)

3. Operasionalisasinya menggunakan falsafah bisnis yang berakar dari budaya lokal (local wisdom )

4. Bidang usaha yang dijalankan berdasarkan pada potensi dan hasil informasi pasar

5. Keuntungan yang diperoleh ditujukan untuk meningkatkan kesejahteraan masyarakat melalui kebijakan desa (village policy)

6. Difasilitasi oleh Pemerintah, Pemprov, Pemkab, dan Pemdes

7. Pelaksanaan operasionalisasi dikontrol secara bersama (Pemdes,BPD, dan anggota)

\section{Perkembangan BUMDes}

Berdasarkan Peraturan Menteri Desa No 4 Tahun 2015, ada beberapa paramaeter atau indikator yang digunakan untuk melihat perkembangan Badan Usaha Milik Desa (BUMDes) itu sendiri. Indikator-indikator tersebut meliputi:

1. Kelembagaan

2. Aturan/ Legalitas

3. Usaha BUMDes

4. Adminitrasi, Pelaporan dan Pertanggungjawaban

5. Permodalan dan Aset

6. Dampak terhadap Masyarakat dan Desa

\section{Teori Kelembagaan}

Menurut Erani, (2006) kelembagaan diberi predikat sebagai kerangka hukum atau hak-hak alamiah (natural rights) yang mengatur tindakan individu. Pada saat yang lain, kelembagaan dimengerti sebagai apapun yang bernilai tambahan atau kritik terhadap ilmu ekonomi klasik atau hedonik (hedonic economics).

Bahkan, kelembagaan juga dimaknai sebagai apapun yang berhubungan dengan "perilaku ekonomi" (economic behavior). Secara definitif, kelembagaan bisa pula dimaknai sebagai regulasi perilaku yang secara umum diterima oleh anggota-anggota kelompok sosial, untuk perilaku spesifik dalam situasi yang khusus, baik yang bisa diawasi sendiri maupun dimonitor oleh otoritas luar (external authority) Rutherford (1994) dalam Erani (2006). Selanjutnya, pendefinisian kelembagaan bisa dipilah dalam dua klasifikasi. Pertama, bila berkaitan dengan proses, maka kelembagaan merujuk kepada upaya untuk mendesain pola interaksi antarpelaku ekonomi sehingga mereka bisa melakukan kegiatan transaksi.

\section{Kelembagaan Desa}

Kelembagaan desa yang dimaksud adalah lembaga, pihak, atau institusi yang berada di desa yang berasal dari unsur eksekutif, legislatif, dan masyarakat yang terlibat dalam penyusunan, pelaksanaan, dan pengawasan anggaran pendapatan dan belanja desa (APBDes). Kelembagaan desa yang dimaksud dalam penulisan ini adalah mengenai kelembagaan keuangan. 


\section{Perkembangan Usaha}

Perkembangan usaha adalah suatu bentuk usaha kepada usaha itu sendiri agar dapat berkembang menjadi lebih baik lagi dan agar mencapai pada satu titik atau puncak menuju kesuksesan. Perkembangan usaha di lakukan oleh usaha yang sudah mulai terproses dan terlihat ada kemungkinan untuk lebih maju lagi.

Menurut Soeharto Prawirokusumo (2010:185-188), perkembangan usaha dapat dibedakan menjadi 5 tahap, yaitu tahap conceptual, start up, stabilisasi, pertumbuhan (growth stage), dan kedewasaan. Dikajian ini akan membahas perkembangan usaha dilihat dari tahapan conceptual, yaitu:

a) Mengenal peluang potensial Dalam mengetahui peluang potensial yang penting harus diketahui adalah masalah-masalah yang ada dipasar, kemudian mencari solusi dari permasalahan yang telah terdeteksi. Solusi inilah yang akan menjadi gagasan yang dapat direalisasikan.

b) Analisa peluang tindakan yang bisa dilakukan untuk merespon peluang bisnis adalah dengan melakukan analisa peluang berupa market research kepada calon pelanggan potensial. Analisa ini dilakukan untuk melihat respon pelanggan terhadap produk, proses, dan pelayanannya.

c) Mengorganisasi sumber daya yang perlu dilakukan ketika suatu usaha berdiri adalah memanejemen sumber daya manusia dan uang. Pada tahap inilah yang sering disebut sebagai tahap memulai usaha. Pada tahap ini dikatakan sangat penting karena merupakan kunci keberhasilan pada tahap selajutnya. Tahap ini bisa disebut sebagai tahap warming up.

d) Langkah mobilisasi sumber daya langkah memobilisasi sumber daya dan menerima resiko adalah langkah terakhir sebelum ke tahap start up.

\section{Metode Penelitian}

Jenis penelitian adalah penelitian deskriptif dengan pendekatan kualitatif untuk memperoleh gambaran atau menguraikan persepsi responden sesuai dengan variabel yang digunakan peneliti. Metode deskriptif adalah metode yang digunakan untuk menggambarkan atau menganalisis suatu hasil penelitian tetapi tidak untuk membuat kesimpulan yang lebih luas.

Penelitian ini menggunakan pendekatan kualitatif dengan jenis penelitian deskriptif. Metode kualitatif sebagai prosedur penelitian yang menggunakan data deskriptif berupa kata-kata tertulis/lisan dari orang-orang dan perilaku yang diamati. Selanjutnya, penelitian deskriptif digunakan untuk memecahkan atau menjawab permasalahan yang sedang dihadapi pada situasi sekarang. Dilakukan dengan menempuh langkah-langkah menghimpun informasi/pengumpulan data, klasifikasi, dan analisis data, interpretasi, membuat kesimpulan dan laporan.

Jenis data yang digunakan adalah data sekunder Data sekunder adalah data yang telah lebih dahulu dikumpulkan dan dilaporkan oleh organisasi di luar penelitian itu sendiri, walaupun yang dikumpulkan itu sesungguhnya adalah data asli. Data ini sudah diolah lebih lanjut dan disajikan oleh pihak pengumpul data primer atau pihak lain misalnya dalam bentuk narasi, tabel-tabel atau diagram-diagram. Dalam penelitian ini data yang diperoleh dari data sekunder berupa profil daerah penelitian, profil BUMDes, data penduduk desa di Kecamatan Kabawetan serta data-data lain yang terkait dengan BUMDes yang peneliti peroleh dari media publik.

Metode analisis data pada penelitian ini menggunakan metode deskriptif, dimana merupakan metode penelitian yang digunakan untuk menggambarkan masalah yang terjadi pada masa sekarang atau yang sedang berlangsung, bertujuan untuk mendeskripsikan apa-apa yang terjadi sebagaimana mestinya pada saat penelitian dilakukan. Sudjana (2001:64) mendefinisikan penelitian deskriptif adalah "Penelitian yang berusaha mendeskripsikan suatu gejala, peristiwa, 
kejadian yang terjadi pada saat sekarang". Metode analisis ini digunakan untuk melihat kondisi BUMDes. Hal yang dideskripsikan yaitu berupa legalitas, penyertaan modal, kepengurusan dan jenis usaha yang dimilik BUMDes.

\section{HASIL DAN PEMBAHASAN}

\section{Legalitas}

Tabel 1 Legalitas BUMDes

\begin{tabular}{|c|c|c|c|c|c|}
\hline No & Desa & $\begin{array}{c}\text { Nama } \\
\text { BUMDes }\end{array}$ & Perdes & SK Pengelola & $\begin{array}{l}\text { Tahun } \\
\text { Berdiri }\end{array}$ \\
\hline 1 & $\begin{array}{l}\text { Bandung } \\
\text { Baru }\end{array}$ & $\begin{array}{l}\text { Maju } \\
\text { Sejahtera }\end{array}$ & $\begin{array}{l}\text { Perdes No. } 03 \\
\text { Tahun } 2017\end{array}$ & $\begin{array}{l}\text { No. 17/ Bumdes/ } \\
\text { V/ } 2017\end{array}$ & 2017 \\
\hline 2 & $\begin{array}{l}\text { Bandung } \\
\text { Jaya }\end{array}$ & Giri Arta & $\begin{array}{l}\text { Perdes No. } 03 \\
\text { Tahun } 2017\end{array}$ & $\begin{array}{l}\text { No. 17/ Bumdes/ } \\
\text { V/ } 2017\end{array}$ & 2017 \\
\hline 3 & Tugu Rejo & Margi Laras & $\begin{array}{l}\text { Perdes No. } 03 \\
\text { Tahun } 2017\end{array}$ & $\begin{array}{l}\text { No. 17/ Bumdes/ } \\
\text { V/ } 2017\end{array}$ & 2017 \\
\hline 4 & $\begin{array}{l}\text { Babakan } \\
\text { Bogor }\end{array}$ & Mandiri & $\begin{array}{l}\text { Perdes No. } 33 \\
\text { Tahun } 2016\end{array}$ & $\begin{array}{l}\text { No. 32/ Bumdes/ } \\
\text { VIII/2016 }\end{array}$ & 2016 \\
\hline 5 & $\begin{array}{l}\text { Pematang } \\
\text { Donok }\end{array}$ & Sejahtera & $\begin{array}{l}\text { Perdes No. } 06 \\
\text { Tahun } 2017\end{array}$ & $\begin{array}{l}\text { No. } 21 \text { Tahun } \\
2017\end{array}$ & 2017 \\
\hline 6 & $\begin{array}{l}\text { Sido } \\
\text { Makmur }\end{array}$ & $\begin{array}{l}\text { Trijaya } \\
\text { Makmur }\end{array}$ & $\begin{array}{l}\text { Perdes No. } 15 \\
\text { Tahun } 2017\end{array}$ & $\begin{array}{l}\text { No. } 16 \text { Tahun } \\
2017\end{array}$ & 2017 \\
\hline
\end{tabular}

Sumber: Dinas Pemberdayaan Masyarakarat dan Desa Provinsi Bengkulu, 2018

Pendirian BUMDes dilakukan melalui persiapan yang matang dan harus memastikan aspek legalitas, karena pada dasarnya legalitas merupakan aspek yang penting dalam berkembangnya suatu usaha. Maka pada Tabel 4.8 dapat dilihat bahwa BUMDes di keenam desa tersebut telah memiliki Perdes. Untuk SK pengelola pada BUMDes Maju sejahtera, Giri Arta, dan Margi Laras adalah No. 17/ Bumdes/ V/ 2017. Sedangkan untuk BUMDes Mandiri adalah No. 32/ Bumdes/ VIII/2016, Sejahtera dengan SK No. 21 Tahun 2017 dan BUMDes TriJaya Makmur yaitu No.16 Tahun 2017. BUMDes di Kabawetan rata-rata berdiri pada tahun 2017.

\section{Penyertaan Modal}

Tabel 2 Penyertaan Modal BUMDes

\begin{tabular}{cllc}
\hline No & \multicolumn{1}{c}{ Desa } & \multicolumn{1}{c}{ Nama BUMDes } & Penyertaan Modal \\
\hline 1 & Bandung Baru & Maju Sejahtera & 122.000 .000 \\
2 & Bandung Jaya & Giri Arta & 114.000 .000 \\
3 & Tugu Rejo & Margi Laras & 108.000 .000 \\
4 & Babakan Bogor & Mandiri & 129.000 .000 \\
5 & Pematang Donok & Sejahtera & 114.000 .000 \\
6 & Sido Makmur & Trijaya Makmur & 106.000 .000 \\
& Rata-rata & & 115.500 .000 \\
& Minimal & 106.000 .000 \\
\multicolumn{2}{l}{ Maksimal } & 129.000 .000 \\
\hline \multicolumn{2}{l}{ Sumber: Dinas Pemberdayaan Masyarakarat dan Desa Provinsi Bengkulu, 2018 }
\end{tabular}


Persoalan modal dan keuangan merupakan aspek yang sangat penting dalam kegiatan suatu usaha. Tanpa memiliki modal suatu usaha tidak akan dapat dapat berjalan walau syarat lain telah terpenuhi. Pada penilitian ini hanya ada di enam desa pertama dimana desa tersebut yang memiliki jumlah penyertaan modal yang yang tertinggi, Dilihat dari Tabel 4.9 rata-rata penyertaan modal di keenam desa tersebut yaitu 115.500.000. Untuk yang tertinggi terletak pada BUMDes Mandiri yaitu dengan nominal 129.000.000 juta. Dan untuk yang terendah terletak pada BUMDes Trijaya Makmur. Penyertaan BUMDes itu sendiri berasal dari pemerintah tanpa ada campur tangan dari pihak ketiga maupun dari sumbangan masyarakat.

\section{Kepengurusan BUMDes}

Pengurus merupakan orang yang terlibat dalam usaha BUMDes. Ada beberapa syarat yang tertuang dalam pasal 14 Permendesa No.14 tahun 2015, yaitu: warga desa yang memiliki jiwa wirausaha yang kuat, berkepribadian baik, berpendidikan minimal setingkat SMU/Madrasah Aliyah/ SMK sederajat. Kepengurusuan BUMDes di Kecamatan Kabawetan terdiri dari unsur pemerintah desa, BPD, Lembaga Desa dan unsur Masyarakat. Komposisi kepengurusan BUMDes di Kecamatan Kabawetan berdasarkan AD-ART yaitu:

a. Dewan Komisaris/Penanggungjawab dijabat oleh Kepala Desa atau Ketua BPD.

b. Dewan Direksi dijabat oleh Ketua LPMD(Lembaga Pemberdayaan Masyarakat Desa)

c. Pengelola dan kepala unit usaha merupakan masyarakat yang termasuk dalam persyaratan kepengurusan yag ditetapkan melalui musyawarah pemerintah desa dan masyarakat.

\section{Jenis Usaha BUMDes}

Tabel 3 Jenis Usaha BUMDes

\begin{tabular}{clll}
\hline No & \multicolumn{1}{c}{ Desa } & \multicolumn{1}{c}{ Nama BUMDes } & \multicolumn{1}{c}{ Jenis usaha } \\
\hline 1 & Bandung Baru & Maju Sejahtera & Toko bangunan \\
2 & Tugu Rejo & Margi Laras & Toko sembako \\
3 & Babakan Bogor & Mandiri & Ayam ras petelur \\
4 & Pematang Donok & Sejahtera & Sewa alat tarub, toko sembako \\
5 & Sido Makmur & Trijaya Makmur & Rental sepeda toko sembako \\
6 & Bandung Jaya & Giri Arta & Toko bangunan, toko sembako, \\
& & & PPOB, Saprotan, Pengolahan Kopi \\
\hline
\end{tabular}

Sumber: Dinas Pemberdayaan Masyarakarat dan Desa Provinsi Bengkulu, 2018

Usaha merupakan suatu hal yang paling penting dalam BUMDes. Tanpa ada usaha BUMDes tidak mungkin berjalan. Ada berbagai macam jenis usaha yang dapat di kembangkan oleh BUMDes baik berupa jasa maupun perdaganggan. Di lihat dari Tabel 4.10 jenis usaha yang terdapat pada keenam desa merupakan usaha dalam bentuk perdaganggan, dimana rata-rata membuka usaha toko sembako. Sebab usaha tersebut cukup mudah untuk dijalankan. Dan pada BUMDes Giri Arta jenis usaha yang mereka jalankan lebih beragam daripada BUMDes yang lain.

Penelitian ini menggunakan metode analisis deskriptif kualitatif untuk menganalisis kondisi BUMDes di Kecamatan Kabawetan Kabupaten Kepahiang. BUMDes merupakan program yang diciptakan pemerintah dalam usaha meningkatkan ekonomi desa berdasarkan kebutuhan masyarakat dan potensi desa yang pengelolaan sepenuhnya dilaksanakan oleh masyarakat desa. Dengan adanya BUMDes diharapkan mampu untuk menciptkan pembangunan ekonomi desa yang lebih baik. Pembangunan ekonomi adalah suatu proses yang menyebabkan pendapatan perkapita suatu masyarakat meningkat, dimana jika kenaikan pendapatan perkapita yang mencerminkan kesejahteraan ekonomi masyarakat. Ada beberapa manfaat yang diperoleh dari pembangunan ekonomi, salah satunya adalah mengurangi penggangguran dan meningkatnya 
kemakmuran. Sejalan dengan adanya BUMDes diharapkam juga mampu membuat masyarakat yang ada di desa dapat mengembangkan ekonomi mereka.

Hasil penelitian kondisi BUMDes di Kecamatan Kabawetan Kabupaten Kepahiang di peroleh hasil yang baik. Hal tersebut dibuktikan dengan telah terbentuknya BUMDes dengan disertai Perdes dan SK Pengelola. BUMDes di Kecamatan Kabawetan rata-rata berdiri dari tahun 2016 dan 2017.

Penyertaan modal BUMDes seutuhnya berasal dari pemerintah, tidak ada campur tangan dari pihak ketiga. Berdasarkan penelitian diperoleh rata-rata penyertaan modal BUMDes sebesar 115.500.000 juta. BUMDes yang paling baik terletak di BUMDes Giri Arta. Pada BUMDes tersebut kinerja yang di hasilkan sudah baik. Dengan penyertaan modal yang tidak begitu tinggi BUMDes tersebut mampu memperoleh keuntungan. Berbeda dengan BUMDes yang lain Giri Arta telah memyerahkan laporan ke Dinas Pemberdaayaan Masyarakat dan Desa (PMD) tentang keuntungan dan omset yang telah di dapatkannya. Sementara untuk kelima BUMDes yang lain belum memberikan laporan mengenai keuangan ,mereka ke dinas terkait tersebut.

Kemudian kepengurusan BUMDes terdiri dari unsur pemerintah desa, BPD, Lembaga Desa dan unsur Masyarakat. Pengurus BUMDes dipilih berdasarkan beberapa syarat, yang kemudian ditetapkan berdasarkan musyawarah desa.

Untuk jenis usaha BUMDes bergerak di bidang perdagangan. Dimana usaha tersebut seperti took sembako. Dengan adanya perdagangan tersebut masyarakat mampu untuk memenuhi kebutuhan sehari-hari mereka, tanpa perlu keluar dari desa untuk mendapatkannya. Jenis usaha yang paling banyak terdapat di BUMDes Giri Arta.

\section{KESIMPULAN DAN SARAN}

Berdasarkan hasil penelitian di atas maka dapat di simpulkan bahwa :

Kondisi BUMDes sudah berjalan baik. BUMDes telah didirikan sejak tahun 2016 dan 2017. Pada BUMDes tersebut penyertaan modal rata-rata yaitu 115.500.000. Untuk yang tertinggi pada BUMDes Mandiri dan yang terendah BUMDes Trijaya Makmur. Kepengurusan BUMDes terdiri dari unsur pemerintah desa, BPD, Lembaga Desa dan unsur Masyarakat. Jenis usaha BUMDes bergerak dibidang perdagangan. Kemudian untuk BUMDes yang paling baik ada pada BUMDes Giri Arta (desa Bandung Jaya) hal tersebut dilihat dari jenis usaha yang ada bentuknya sudah beragam dibandingkan dengan BUMDes yang lain.

Berdasarkan hasil penelitian yang telah disimpulkan, maka diajukan saran yaitu:

Untuk beberapa BUMDes menambah jenis unit usaha yang bergerak pada usaha selain dagang sehingga masyarakat lebih banyak mendapatkan berbagai usaha untuk memenuhi kebutuhan kehidupan mereka. Selain itu dengan menambah jenis usaha juga bisa meningkatkan pendapatan desa. BUMDes yang ada di Kecamatan Kabawetan diharapkan bisa memberikan laporan mengenai keuntungan dan omset yang diterima ke Dinas Pemberdayaan Masyarakat dan Desa. Untuk beberapa BUMDes yang belum begitu bagus dalam penyelanggarannya di harapkan bisa meningkatkan kinerjanya untuk lebih baik lagi. Untuk dinas terkait diharapkan lebih memantau kinerja yang dilakukan.

\section{DAFTAR PUSTAKA}

Agunggunanto,dkk.2016. Pengembangan Desa Mandiri Melalui Pengelolaan Badan Usaha Milik Desa (BUMDes), Jurnal Dinamika Ekonomi dan Bisnis. 3(1): 1-10.

Ali Sudarman. 1992. Teori Ekonomi Mikro. Yogyakarta: BPFE. 
Alkadafi. 2014. Penguatan Ekonomi Masyarakat Melalui Pengelolaan Kelembagaan Badan Usaha Milik Desa Menuju Asean Economic Community 2015.Jurnal El-Riyasah, 1(1): 1-15.

Andriani 2017. Pengaruh Bumdes Terhadap Pengembangan Ekonomi Desa Di Kecamatan Perbaungan Kabupaten Serdang Bedagai. Skripsi Fakultas Ekonomin dan Bisnis Universitas Sumatera Utara. Medan. Di Publikasikan. https://repository.usu.ac.id/

Aqmarina. 2017. Keberadaan Badan Usaha Milik Desa (Bumdes) Terhadap Kesejahteraan Masyarakat Desa Ponggok, Kecamatan Polanharjo, Kabupaten Klaten, Provinsi Jawa Tengah. Skripsi Fakultas Ekonomi dan Bisnis Universitas Diponegoro. Semarang. Tidak di Publikasikan. https://eprints.undip.ac.id/.

Arsyad. 2010. Ekonomi Pembangunan (Edisi Ke-5).Yogyakarta: Unit Percetakan STIM YKPN Yogyakarta.

Badan Pusat Statistik Kabupaten Kepahiang. 2018. Kecamatan Kabawetan Dalam Angka. BPS Kepahiang, Kepahiang.

Boediono. 1981. Teori Pertumbuhan Ekonomi. Yogyakarta: BPFE

Bryant dan Louise. 1987. Manajemen Pembangunan Untuk Negara Berkembang. Jakarta: LP3ES

Departemen Pendidikan Nasional Pusat Kajian Dinamika Sistem Pembangunan (PKDSP), 2007, Buku Panduan Pendirian dan Pengelolaan Badan Usaha Milik Desa (BUMDes), Jakarta: Fakultas Ekonomi Universitas Brawijaya.

Dinas Kependudukan dan Pencatatan Sipil Provinsi Bengkulu. 2018.

Dinas Pemberdayaan Masyarakat dan Desa Provinsi Bengkulu 2018.

Erani. 2006. Ekonomi Kelembagaan; definisi, teori dan strategi. Malang: Bayu Media.

Garnies, Lellyana. 2017. Peran Badan Usaha Milik Desa (Bumdes) Dalam Meningkatkan Kesejahteraan Masyarakat Desa Berdasarkan UU No. 6 Tahun 2014 Tentang Desa (Studi Kasus Di Bumdes Tirta Mandiri Klaten).Skripsi Fakultas Ilmu Hukum Universitas Muhammadiyah Surakarta. Surakarta. Di Publikasikan. https://eprints.ums.ac.id/

Hudi Setyobakti. 2017. Identification Of Business Entreprises Bumdes Based On Social and Economic Aspect(Case Study At Bumdes Ijen Lestari Tamansari Village District Of Banyuwangi). Jurnal Ilmiah Bidang Akuntansi dan Manajemen. 14 (2):1-10.

Ihsan, Ahmad. 2018. Analisis Pengelolaan Badan Usaha Milik Desa (BUMDes) Gerbang Lentera Sebagai Penggerak Desa Wisata Lerep. Skripsi Fakultas Ilmu Sosial dan Ilmu Politik Universtas Diponegoro. Tidak di Publikasikan. https://ejournal3.undip.ac.id/

Jhingan. 2004. Ekonomi Pembangunan dan Perencanaan. Jakarta: PT Raja Grafindo Persada.

Maryunani. 2008. Pembangunan Bumdes dan Pemerdayaan Pemerintah Desa. Bandung: CV Pustaka Setia

Morni, Kasila. 2017. Partisipasi Pemuda Desa Dalam Perkembangan Usaha Bumdes "Tirta Mandiri (Studi Di Desa Ponggok, Kecamatan Polanharjo, Kabupaten Klaten, Provinsi Jawa Tengah). Skripsi Fakultas Ekologi Manusia Universitas Pertanian Bogor. Bogor. Di Publikasikan. https://repository.ipb.ac.id/.

Nazir. 1988. Metode Penelitian. Jakarta: Ghalia Indonesia. 
Prawirokusumo, Soeharto. 2010. Kewirausahaan dan Manajemen Usaha Kecil EdisiPertama. Yogyakarta: BPFE UGM

Republik Indonesia. 2010. Peraturan Desa No 6 tahun 2010 tentang pendirian Bumdes.

Republik Indonesia. 2015. Peraturan Menteri Desa, Pembangunana Daerah Tertinggal, dan Transmigrasi No 4 Tahun 2015 Tentang Pendirian, Pengurusan dan Pengelolaan, Dan Pembubaran Badan Usaha Milik Desa.

Rudy Badrudin. 2012. Ekonomika Otonomi Daerah. Yogyakarta: UPP STM YKPN

Sudjana. 2001. Penelitiam dan Pendidikan. Bandung: Sinar Baru

Sukirno, Sadono. 1994. Pengantar Teori Makro Ekonomi, Edisi Kedua. Jakarta: Rajawali Pers.

Sugiyono. 2009.Metode Penelitian Kuantitatif, Kualitatif dan R\&D. Bandung: Alfabeta.

Sugiyono. 2010. Metode Penelitian Pendidikan Kuantitatif, Kualitatif dan R\&D. Bandung: Alfabeta

Supranto, 2003. Tekhnik Sampling. Jakarta: Salemba Empat.

Tjahya Sumodiningrat. 2000. Strategi Pembangunan dan Kemiskinan. Jakarta:Rineka Cipta

Todaro, Michael P \& Stephen C. Smith. 2003. Economic Development, Eight Edition. England: Pearson Education Limited.

Tri \& Antyo. 2006. Aspek Dasar Ekonomi Mikro. Jakarta: PT Grasindo.

Tumpal. 2004. Mewujudkan Otonomi Masyarakat Desa Alternatif Pemberdayaan Masyarakat. Jakarta: IRE Press

Umi Hidayati, dkk. 2015. Analysis of Education and Training Needs To Increase BUMDes Management Capacity in Developing Business Units. Jurnal Bisnis Dan Manajemen. 7 (23): $1-20$.

Widjojo Nitisastro. 2010. Pengalaman Pembangunan Indonesia. Jakarta: PT. Kompas Media Nusantara

Yudhistira dan Anshory. 2017. Analisis Pengaruh Bumdes Dalam Meningkatkan Ekonomi Pedesaan Di Kabupaten Situbondo. Skripsi Fakultas Ekonomi Universitas Abdurachman Saleh. Situbondo. Tidak di Publikasikan. https://unars.ac.id/

Yunanto, Sutoro Eko., dkk. 2013. Membangun BUMDes yang Mandiri, Kokoh, dan Berkelanjutan. Forum Pengembangan Pembaharuan Desa (FPPD). 